\title{
SPACES, TIMES AND CRITICAL MOMENTS: A RELATIONAL TIME- SPACE ANALYSIS OF THE IMPACTS OF AIDS ON RURAL YOUTH IN MALAWI AND LESOTHO
}

\author{
NICOLA ANSELL, \\ Centre for human Geography \\ BRUNEL UNIVERSITY \\ KINGSTON LANE \\ UXBRIDGE \\ UB8 3PH \\ 01895266085 \\ NiCOLA.ANSELL@BRUNEL.AC.UK
}

LORRAINE VAN BLERK, UNIVERSITY OF DUNDEE

FLORA HAJDU, UPPSALA UNIVERSITY

ELSBETH ROBSON, BRUNEL UNIVERSITY AND UNIVERSITY OF MALAWI 


\section{SPACES, TIMES AND CRITICAL MOMENTS: A RELATIONAL TIME- SPACE ANALYSIS OF THE IMPACTS OF AIDS ON RURAL YOUTH IN MALAWI AND LESOTHO}

\section{ABSTRACT}

Southern Africa's AIDS epidemic is profoundly spatially and temporally structured; so too are the lives of the young people whose families it blights. In this paper we draw on qualitative research with AIDS-affected young people in Malawi and Lesotho, and recent work theorising time-space in human geography, to examine how time-spaces of AIDS-related sickness and death intersect with the time-spaces of young people and, importantly, those of their relations with others to produce differentiated outcomes for young people. We also explore the time-spaces of those outcomes and of young people's responses to them. The paper concludes that a relational timespace analysis of the impacts of AIDS on young people helps explain the diversity of those young people's experiences and allows AIDS to be contextualised more adequately in relation to everyday life and young people's wider lifecourses and their relationships with others. Moreover, the research points to the significance of the time-space structuring of society in shaping the outcomes of familial sickness and death for young people.

\section{INTRODUCTION}

The impacts of AIDS on young southern Africans have been widely researched, but while attention has been given to spatial aspects of the relationship between AIDS and its consequences (e.g. Booysen 2006; Ford and Hosegood 2005; van Blerk and Ansell 2006), temporal aspects remain under-researched. Indeed, temporality has been neglected in youth geographies more generally (Worth 2009). Yet AIDS-related sickness and death have distinct temporalities that interweave with their spatialities. This paper draws on recent work theorising time-space in human geography (Massey 2005; Crang 2005; Dodgshon 2008) to examine the time-spaces of young people's experiences of AIDS. In particular, it draws on notions of time-space as heterogeneous and relational, kairological and topological, rather than 
Cartesian or linear (Cope 2007, Panelli 2007), to draw attention to how the time-space structuring of society, including young people's everyday lives and transitions to adulthood shape the outcomes of familial sickness and death in diverse and unpredictable ways.

The paper begins by considering how geographers and others have theorised space, time and time-space, and how these conceptualisations may illuminate young people's lives. The timespace structuring the lives of young southern Africans is considered, and the research methodology introduced. Drawing on interviews and lifemaps produced by young people from Malawi and Lesotho, we explore how time-spaces of AIDS-related sickness and death (the timing, duration, sequencing, location, associated mobilities) intersect with the time-spaces of young people's lives (age, stage of schooling, marital status, location, mobilities) and of their relations with others to produce differentiated outcomes for young people. Using one young man's life as a case study, we further examine how those outcomes, and young people's responses to them, in turn produce new time-spaces. We draw a number of conclusions concerning how a time-space lens reveals new understanding of AIDS' diverse outcomes.

\section{THEORISING SPACE AND TIME IN YOUNG RURAL LIVES}

Both space and time are significant in the construction of childhood and youth, producing variations in how childhood and youth are perceived, understood and experienced over time and between places. But the influences of spatiality and temporality extend far beyond these crude distinctions. In this section we explain the value of a relational time-space approach.

\section{SPACE, TIME AND TIME-SPACE}

Human geographers increasingly view both time and space as socially constructed and relational; not neutral containers in which things happen, but existing only in and through happenings and relations (Dodgshon 2008; Massey 2005). But space and time also shape social life and human subjectivity: '[w]e do not develop some notion of the human subject and then insert it into grids of space and time. Rather the subject is formed through structures of temporality and spatiality' (Crang 2005:208). Geographers have also begun to valorise experiential or 'kairological' time, which they distinguish from chronological 'clock time'. Some 
view it as more real (Dodgshon 2008); as ontological rather than epistemological (Uprichard 2008). Like the problematic pairing of place and space (Massey 2005), however, a dualistic binary of kairological and chronological time is unhelpful. From a relational perspective, calendared or chronometered times are proxy measures (Dodgshon 2008), ways of experiencing time that are fundamentally cultural. While arguably 'unreal' (Schatzki (2006) echoes Bergson's view that 'real' time is continuous and cannot be decomposed to discrete instants in the way imagined of 'objective' time), chronological time nonetheless enables humans to coordinate their activities and investigate the world (Schatzki 2006).

Once linear chronological time is relegated to an abstraction, other dimensions of time come to the fore. Adam (2004) identifies five temporal dimensions: 'temporality', referring to duration; 'time frame', reflecting how actions relate to each other in time (whether simultaneous or sequential, for instance); 'time point', meaning the frequency and sequence of the action (for instance, whether it is cyclical); 'tempo', relating to causes, consequences and connections between phenomena; and 'timing', meaning the ability of people to take opportunities, to miss them or find them precluded. While we consider this particular terminology unduly oblique, recognition that human practices have significant durations, sequences and timing which shape their outcomes (Shove 2007) is fundamental to our analysis. Everyday time, composed principally of repetition and routine (thus circular rather than linear) (Crang 2005), constitutes the fabric of daily life and builds the 'temporal rhythms' of societies (Panelli 2007). Through synchronisation and contingency 'individuals and groups organise their lives in relation to others, society and its institutions' (Bailey 2009:409). Moreover, through 'continual sequential and overlapping performances' (Schatzki 2006:179), change is produced.

Space and time not only pose similar analytical challenges, they are fundamentally intertwined: it is impossible to conceptualise one existing without the other (Massey 2005). It is therefore useful to think in terms of 'time-spaces' that are relational, 'constructed out of the articulation of trajectories' (Massey 2005:179), fragmented and dynamic, and constituted through relationships that are organised and reorganised through networks, flows and mobilities (Ellegård and Vilhelmson 2004). Like space, relational time-spaces are not neutral but involve 
complex geometries of power relations and meanings (Panelli 2007). Time-spaces are also scaled, spatially and temporally, encompassing short-lived (yet transformational) events, longstanding long-distance relationships, daily local journeys or international migrations. Much as local and global are co-implicated, 'reality contains a sequence or continuity of durations of different scales, or breadths' (Schatzki 2006:162), and both daily routines and significant moments co-constitute the long-term transformation of everyday life.

Transformation is central to time-space. Gregory (2009) describes time-space as a process of continual construction. Massey (2005:189) stresses time-spaces are 'always open, being made'. Agency does not lie simply with individuals, but change is produced 'through practices of interrelation' (Massey 2005:55), which also actively involve the biophysical environment (including, for instance, AIDS) (Massey 2005). Transformation is attributable both to ongoing everyday happenings and key events, the time-sensitivity of the latter determining whether they become turning points in structural change (Panelli 2007). In this paper we use the term 'time-space structuring', to refer to how the times and spaces humans and nature construct, materially and discursively, constrain social actors as well as providing materials from which to produce change.

\section{SPACE, TIME AND TIME-SPACE IN YOUNG LIVES}

Extensive research in children's geographies has demonstrated the significance of space and place for young people's experiences and identities (Ansell 2009; Skelton 2009). Spatially structured political-economic processes produce spatially uneven lifechances (Katz 2004; Ruddick 2003). Yet space and place are not static determinants of young people's lives. In constructing identities and lifestyles, young people actively engage with places at multiple scales, directly through mobilities (Kraftl et al 2009) and migration (Dobson and Stillwell 2000; Punch 2007), and indirectly, for example, through internet communication or purchasing commodities (Holloway and Valentine 2000; Hörschelmann and Schafer 2005; Massey 1998).

Children's geographers have been less attentive to temporal aspects of young lives, largely in reaction to the historic dominance of developmentalist studies that treated children as human becomings, not human beings with lives worth studying in their own right (James et al 1998). 
This emphasis on 'adults-in-waiting', however, continues to suffuse studies of youth transition. Research inspired by Giddens (1991) and Beck (1994) has explored patterns and practices of leaving school, starting work, leaving home, marriage and childbearing (Jones and Wallace 1992; McDowell 2002), focusing on pathways through which youth become independent, individualised adults (Bilari et al 2001; Heaton et al 2002). More critical studies have advocated a relational approach, exploring the roles of families and peers (Hopkins and Pain 2007; Langevang 2008) and other generations (Tucker 2003), as well as contexts of poverty (van Blerk 2008) and recognising that the endpoint of transition may be 'negotiated interdependence' (Punch 2002) rather than independence. Broader relational concepts of lifecourse also allow for exploration of other events and transitions punctuating individuals' lives, beyond those examined in youth transition studies (Bailey 2009), including unexpected 'fateful moments' (Worth 2009), 'vital conjunctures' (Langevang 2008) and rites of passage (Teather 1999). These may contribute to a 'processual and non-linear transition' rather than neat transfers between distinct life stages (Langevang 2008:2040). Research has also begun to examine how lifecourses are built over time, with accumulations of experiences, resources, and vulnerabilities shaping subsequent lifechances (Bailey 2009), as well as the role of wider processes (Hopkins and Pain 2007; Langevang and Gough 2009).

Few studies of lifecourse have engaged with explicit theorisations of temporality; most espouse a linear view of time (Worth 2009) and future orientation. Recent work has, however, engaged with non-linear conceptions of time to understand childhood as 'going on' rather than 'growing up' (Horton and Kraftl 2006), as 'being and becoming'(Uprichard 2008), with multiple becomings encountered throughout the lifecourse (Worth 2009). Viewing time as relational and kairological (while recognising the utility of abstract measures of time), illuminates both the long term trajectories of young people's lives and their day-to-day experiences. Thus children may be understood as 'social actor[s] constructing [their] everyday li[ves] and the world around them, both in the present and the future' (Uprichard 2008:311).

Few studies of young lives have given explicit attention to time-space. Harker (2005) and Horton (2008) have explored children's time-space routines. Cope (2007) contrasts the self- 
oriented, process focused, fluid and flexible time-spaces of children and youth, with the routinised, precise and results- and outcomes-oriented time-spaces of adults. Worth (2009) is interested in young people's perceptions of temporality, and how they narrate key transition moments. More common, if somewhat limited, engagements with the concept of time-space have focused on mobility patterns over the lifecourse, for instance linking lifecourse events and stages to residential mobility (Clark and Huang 2003; McHugh et al 1995; Ní Laoire 2008). Some recent research has adopted a relational approach, emphasising the family lifecourse processes that underlie individual migrations (Cooke 2008; De Jong and Roempke Graefe 2008). However, time-spaces are relational in far more diverse and complex ways than these studies have identified. In the discussion that follows, we explore relational time-spaces at multiple scales, identifying how they constrain and are produced by young people dealing with the consequences of AIDS.

\section{YOUNG RURAL LIVES IN SOUTHERN AFRICA: TIME-SPACES AND THE}

\section{IMPACTS OF AIDS}

Young people constitute a large proportion of southern Africa's residents: $32 \%$ in Lesotho and 33\% in Malawi are aged 10-24 (US Census Bureau 2009). Yet these young people have received little attention from geographers. While research has highlighted high levels of (accompanied and unaccompanied) youth migration and mobility (Benwell 2009; Ginsburg and Norris 2009; Gough 2008; Richter and Norris 2006; van Blerk and Ansell 2006), there have been few studies

of temporal aspects of young lives. Yet young people's lives are characterised by very distinctive time-space practices that alter over time, and which are changing as a consequence of the AIDS pandemic.

As elsewhere in the world, children in southern Africa occupy and produce distinct time-spaces. Livelihood activities are enacted through particular spaces during particular times and seasons. In Lesotho, for instance, herdboys accompany livestock to mountain pastures in summer, 
staying in makeshift shelters they construct, sometimes for several weeks at a time. ${ }^{1}$ Children engage in forms of agriculture, business, domestic and caring roles which may remove them from their households.

Most young people in Malawi and Lesotho also attend school for several years, a practice that structures the time-spaces of their daily lives and provides a directional, though not uniformly linear, measure of life stage. Primary education comprises seven 'Standards' in Lesotho and eight in Malawi, each of which must be 'passed' to progress to the next class. Ideally, children start school aged six, but many start later (particularly where the journey is arduous). Successful completion of the public examinations marking the end of the primary cycle allows progression to secondary school, provided the much more substantial fees can be paid. For many young people, Standard or Form in school is a more salient indicator of a time in their life (a form of 'social age' Elder 1998) than chronological age or calendar year.

Increasing significance is attached to completion of schooling as a measure of 'successful' youth transition (Ansell 2004). Nonetheless, the key moment in most southern African youth transitions is marriage ${ }^{2}$ which represents an abrupt change of social, economic and, until recently, legal status. Time-spaces of marriage differ markedly between patrilocal Lesotho and matrilocal southern Malawi, although in neither society are practices static or homogeneous (Chanock 1985; Murray 1981). In southern Malawi, a couple are expected to settle in the wife's village, although many remain temporarily in the husband's village until they have built a house. Should the couple divorce, the husband is expected to leave the wife, property and any children (Kachika 2000). Should the wife die, any children traditionally remain with their maternal grandparents or aunts, while the widower leaves taking only personal property. Today, however, some men stay and care for their children (Ali 1998). Conversely, in patrilocal Lesotho, a wife moves to her in-laws' home. She usually, however, gives birth to her first child at her parents' home; the child conventionally also spends some childhood years resident with

\footnotetext{
${ }^{1}$ Observations in this section are based on ethnographic fieldwork conducted in Malawi and Lesotho by the authors over many years.

${ }^{2}$ In both Lesotho and southern Malawi, adulthood was historically attained through formal initiation, enacted through a sharply defined time-space. Diverse initiation practices persist, but are seldom seen as crucial markers of transition.
} 
these grandparents. Following the child's birth, the couple generally build their own house in the husband's village. Any children belong to the village, and should their parents separate or die, they remain the responsibility of their paternal family, specifically their father's brother (Letuka and Mamashela 1994; Murray 1981). In recent years, however, widowed mothers often return to their natal homes, taking their children, and double orphans are commonly cared for by maternal relatives (Ansell and van Blerk 2004). Importantly, while customary practices remain widespread in rural areas, they are no longer considered a universal template, and in Malawi in particular have long been fluid (Chanock 1985; White 1987).

Another key time-space transformation of many young people's lives is the transition to work, although young people are economically engaged from an early age. Historically, young men from Lesotho and Malawi travelled long distances for employment in South African mines or commercial plantations, which became a rite of passage (Ferguson 1990). Today some young women seek factory or domestic work in town after leaving school. Yet while many school children envisage adult lives characterised by formal paid employment, in practice most engage in informal activities in their local communities (Ansell 2004). In a context in which poverty is ubiquitous and hunger a real risk, young people's time-spaced lifecourse strategies relate to anticipated livelihood benefits, both immediate and long-term. This applies not only to leaving school or finding employment, but also, in many cases, leaving home or marriage. Cope's (2007) suggestion that youth time-spaces are less outcome-oriented than those of adults does not apply here.

Over the past two decades, the AIDS pandemic has profoundly impacted rural young people in Lesotho and Malawi. The effects of orphanhood have been widely charted. Studies have also examined the spatial implications of the pandemic for young people, particularly in terms of migration (van Blerk and Ansell 2006). However, differential experiences and outcomes relating to age or other temporalities have been seriously neglected. In this paper, we examine spatial and temporal aspects of young people's experience of AIDS and of their responses to the indirect impacts the disease has on their lives. 


\section{MAPPING THE TIME-SPACES OF AIDS-AFFECTED RURAL YOUTH IN}

\section{MALAWI AND LESOTHO}

The research reported here was undertaken as part of a study examining how AIDS' impacts on young people are affecting their livelihoods and likely future food security. It focused on two villages in two of the worst affected countries. Nihelo, in densely populated and highly impoverished southern Malawi, was selected as a 'typical' village in a high HIV-prevalence, mixed livelihood area, yet small enough to become acquainted with all the young people. Ha Rantelali in the sparsely populated Maluti Mountains in Lesotho was a comparable village and a site of previous fieldwork (Ansell 1999), allowing a longitudinal perspective on change.

More than thirty self-selected 10-24-year-olds ${ }^{3}$ participated in diverse participatory research activities in each community. Around half the participants in each community had experienced chronic sickness or death among adults in their households (used as a proxy for AIDS, as few are open or knowledgable about causes of disease). The inclusion of (relatively) unaffected young people allowed us to explore with greater confidence the specific impacts of AIDS.

Consistent with an understanding that young people actively produce time-spaces as well as being constrained by them, and that through the research process they can contribute meaningfully to knowledge production, the fieldwork adopted a broadly participatory approach. Reflecting calls to use multiple research methods with African youth (Langevang 2007), diverse structured activities were employed to explore young people's lives and livelihoods. Interpreters were used for translation in the field, and discussions were recorded, transcribed and translated.

\footnotetext{
${ }^{3}$ Although we targeted 10 to 24 year olds, and organised them into groups aged 10-17 and 18-24 (to reflect the UN definition of youth and distinguish between those legally minors and legally adults), many young people, particularly in Malawi, were unsure of their (calendar) age. It became apparent that some participants probably fell outside the allocated age group. Moreover, the age groupings did not match everyone's perceptions of themselves as child or adult, which in the case of young women generally related to their marital status. Hence some unmarried women of 18 or over elected to join the 'girls" group while married 16 and 17 year olds joined the 'women's' group. The lack of saliency of calendar age also meant that many young people narrated life events in relation to the school year they were in at the time.
} 
Methods were needed that enable research with young people to go beyond the 'ethnographic present' (Ennew and Swart-Kruger 2003). We also considered a purely phenomenological uncovering of individual experiences of time-space to be inadequate, and sought additionally to abstract from their accounts and situate their lives in a wider (externally-defined) context to reveal connections and differences, through both data collection methods and analysis. The data presented below derive largely from two sources. A life mapping exercise was designed to uncover young people's mobilities over their lifecourses and the causal connections they perceive between events and situations. Groups of 3-8 young people met outside the researcher's (Hajdu) house in the village. Following discussion about places the young people had visited, they drew a sequence of connected pictures depicting key events and movements over their life course, beginning with birth and projecting into the future. We have found drawing methods very effective in previous research with African youth, allowing them time to deliberate on and compose narratives before recounting them (van Blerk and Ansell 2006), but recognise that different methods suit different individuals (Langevang 2007). Some older youth in Lesotho and one in Malawi elected not to draw, but proffered oral narratives from which lifemaps were composed. The participants were asked to explain their lifemaps, and then discussed reasons for the differences between them.

This exercise provided valuable insights into the range and patterns of young people's movements, in relation to other lifecourse events. However, the limited time available for individuals to relate their stories, and the public environment, inhibited detailed accounts. We therefore subsequently undertook in-depth life history interviews with more than twenty 18-24 year olds in each village (almost all of those in residence) to further explore the factors shaping their lifecourses and livelihoods. In these the young people were encouraged to talk about short and long-term events and processes, the connections between them and the contexts in which they took place.

Personal histories are inevitably products of 'lived time' wherein '[w] hat we apprehend as past, present and future ... do not have an existence outside of the present' (Dodgshon 2008:7). This poses methodological limitations for research based on personal testimony. For instance, most 
young people attribute much more significance to a parental death in older childhood than one that occurred when they were very young. It is easier to compare 'before and after' than to speculate how life would have been different with a parent they barely remember. While young people were asked to attempt the latter, their responses, particularly in relation to the death of a parent early in their lives, are entirely speculative.

Analysis of the research findings began with participatory group discussions following most of the activities. Evidence that temporal dimensions of the impacts of AIDS were significant in accounting for its impacts quickly became apparent. Data were subsequently entered into NVivo, and temporal and spatial elements of young people's accounts were coded.

\section{THE TIME-SPACES OF AIDS AND ITS OUTCOMES FOR YOUNG PEOPLE}

The stories we elicited from young people reveal many ways in which the time-spaces of AIDS intersect with their own time-spaces, and those of other people, to produce particular outcomes. AIDS is commonly experienced as an interruption to young people's lifecourse trajectories that transforms how lives are subsequently led, spatially and temporally. Data analysis revealed a broad distinction within the narratives between the time-spaces of young people's (contextualized) experiences of AIDS-related sickness and death and the time-spaces of the outcomes of (and their responses to) those experiences (although the chronology is not always as clear as this implies). These elements are addressed in the two sections below.

\section{RELATIONAL TIME-SPACES OF SICKNESS AND DEATH}

In this section we consider how the timing/spacing of AIDS-related sickness and death contribute to the pandemic's indirect impacts on young people. Although sickness and death are often linked (in a particular temporal order), and aspects of the time-spaces and impacts are similar (and indeed closely connected), temporally they are distinct. Sickness has duration and this is significant to its impact; death, on the other hand, is a transformational event. They will thus be considered separately below. Temporal and spatial dimensions are strongly interconnected, although either spacing or timing might predominate in its significance in different instances. Both are relationally constructed. Temporalities for instance include sibling 
order, relationship to the school structure (level achieved, whether still in school or having left); spatialities include the location of the young person relative to the individual who is sick or dies, the location of other family members, and the ease and extent of mobility of all concerned.

\section{SICKNESS}

Temporal aspects of illness affect the impacts on relatives. Illness may be sudden or have a slow onset; constant or recurrent; short-lived or of long duration. The impacts also differ depending on other temporalities including the ordering of events and the season. Sophia's ${ }^{4}$ father, for instance, was sick at ploughing time, and unable to prepare the fields for planting, leaving the family hungry the following year.

The age (biological and in school stage) of affected young people also has consequences. Care for anyone suffering from AIDS-related illness is usually provided from within their own household. Very often young people are involved (see also Robson et al 2006). Expectations concerning appropriate caring roles relate partly to the young person's age, as do the effects on their lives. Those at school may attend irregularly or have to drop out, while others such as Sharon, whose mother became sick after she left school, might be less seriously affected. Sickness of adults can also deprive a household of income, the impacts on young people varying depending on age or schooling stage. Mathabang, who was in Standard 5 when her father became sick, was withdrawn from school because there was no longer money to pay fees or provide uniforms.

More generally, young people in Malawi told us the costs of parental sickness could leave them unable to borrow money from their families during the critical window between leaving school and marrying. This is also a time when social networks are crucially important in helping young people find livelihood opportunities, but those caring for a sick person have little time to devote to friendships and are viewed as unhappy and poor company.

Not only temporal aspects of illness are significant; spatialities are important too. Where their sick relative lives elsewhere, the impact on the young person might be less, or they might be

\footnotetext{
${ }^{4}$ Pseudonyms are used for research participants throughout. The age, gender and country of residence of the young person are only mentioned if it is of clear relevance to the point being made.
} 
required to move to provide care, as Emily did, leaving her new husband temporarily to return home and care for her sick mother. In some instances, sickness prompts a move by the afflicted individual. When, years earlier, Emily's father became sick, he fell out with people where he was living and returned to his original village. She and her mother went with him to look after him.

When a sick person requires hospital care, the time-spaces of sickness can be particularly demanding of young people's time and energy. When David's mother attended hospital to receive antiretroviral treatment, he transported her by bicycle. At one stage she was admitted for over a month. Malawian hospitals expect families to provide personal care and food, so David was allowed out of school for a certain duration each day to care for his mother, a routine repeated following her death when his father became ill. Not only was his schooling affected, but during his father's illness he loaned the household's livestock to a relative, as he had no time to care for them; an action with potential consequences for his future livelihood. These time-spaces of sickness, relating to the patient, the young person, the wider context and their interrelationships, all shape the outcomes for the young person and the severity of the impacts on their subsequent lives.

\section{DEATH}

As with sickness, the impact of a close relative's death on a young person differs according to their age. Effects of parental death on education often reflect the stage of schooling the young person has attained. While Edison, whose father died when he was very young, says he felt the influence of his father's absence throughout his school career, he did complete secondary school (although not with the qualification he would have liked). Some who lost parents as infants had a very truncated education, leaving due to general hardships or specific family stresses, related indirectly to being orphaned. However, those approaching or at the secondary stage particularly feared their father's death would curtail their education. At secondary level remaining in school is often a struggle: the requirements harden, uniforms and fees are costly, the school is usually further away and wavering parental commitment can trigger drop out. In some cases schooling did end with the parent's death - Mamoletsane, for instance, had to 
leave Form B. Others found funding to continue: Mary's uncle paid two years of secondary fees and a bursary covered the following two years; Tumelo received a scholarship for Forms D and E in recognition of his sporting accomplishments. Others, such as Irene, missed a year of schooling, but subsequently returned. Even those with funding faced difficulties: following his parents' deaths, Khotso relocated to his grandmother's home which was a long walk from school, and dropped out partly because of the journey.

The age of a young person when their parent dies also affects their capacity to inherit. Thabo who lost his parents when very young, had to move to another village, losing entitlement to his parents' land. Older children, and those remaining in the parental home, might inherit, but rely on someone else to farm for them. Julita, for instance, rented out the family fields following her parents' death, while young brothers Victor (12) and Blessings (10) farmed the small field they inherited from their mother with the help of their great grandmother.

A response to parental death among some in their mid- to late-teens was to marry. Many young women in Malawi married soon after their fathers' deaths. Milka, for instance, double orphaned at 14 married at 16 due to 'lack of assistance'. Equally, when Emily's first husband died, she remarried quickly to gain economic support. In Lesotho, too, many orphaned girls married young. Mabatho, Mathabang and Mamoletsane were all married as teenagers and without payment of brideprice, the absence of a father-in-law making it possible for their husbands to marry at low cost.

While marriage might be seen as a way of dealing with the loss of financial support from a father, having married was no guarantee that parental death would have no (financial or other) impact. Aleya felt the loss of material support from her mother, who had continued to play an important role even after Aleya's marriage. Julita's father's death (particularly the fact that she disobeyed her husband by returning home for the funeral) ended her three year marriage. Julita also attributed her decision to leave to a belief that her husband was unfaithful and might infect her with a disease, a fear probably related to the recent death of both her parents from 
AIDS $^{5}$. In contrast, Tumelo, having lost both his parents, married in order to lead a more stable life and avoid the risk of contracting AIDS.

While age significantly affects the impacts of a death, these impacts also relate strongly to the spatial relationships between the young person, the deceased and the wider family. The spatial organisation of families, as indicated above, reflects, inter alia, cultural expectations concerning the residence of married couples and their children. Families often do not conform to these expectations, generally because of labour migration or parental separation. Nonetheless, traditionally defined practices remain important to many young people's experiences of their family's spatial structure.

Where a co-resident adult dies, a serious impact might be anticipated. The availability of food often diminishes and psychosocial support is lost, as Marapellang discovered when her brotherin-law and sister-in-law, who shared her homestead, died. There are, nonetheless, many instances of non-resident parents and other providers dying with deleterious effects on a young person's sustenance. Mamoletsane's father had had well-paid mine work in South Africa and his death left the family struggling and her siblings resorting to casual work. Lucy's father died when she was 12 . Although he had left her mother soon after her birth, and lived in town with another wife, he had been paying her school fees. Mabatho's mother died when she was 11 and she and her sister lived alone supported by an aunt who worked in Maseru and provided food, clothing and toiletries. The death of the aunt when she was 16 was very significant. By contrast, Milka's father had divorced her mother and was not supporting the family at the time of his death, and likewise Retselisitsoe's mother had been separated from his father and living elsewhere for nearly 2 years, so her death had little impact on his day-to-day life.

One impact felt by many whose parents died elsewhere was difficulty inheriting, with timespace posing serious obstacles. While Maselloane and her husband inherited her brother-inlaw's fields and half-built house in Ha Rantelali, Edison's father had never lived in Nihelo so there was no property in the village for him to acquire. Several young people would have

\footnotetext{
${ }^{5}$ Julita and brother David were among very few participants who were open about their parents having died of AIDS.
} 
inherited productive equipment from their fathers, but for inability to transport them within the limited time available. Emily's father had carpentry tools in Blantyre where he was working, but her co-resident brother could not afford the transport to collect them and her other brothers, who had been living with their father in town, could not transport them back to the village. They therefore accrued to his landlord. Similarly, Sharon's father died in another district, but she was not invited to collect his belongings. Mary's father transported his belongings to relatives in Mozambique, as he had hoped to relocate there, but he died shortly afterwards, leaving his wife and daughters with little.

In some instances it was the child who was away from the family home when their parent died. Julita was married and living in town, and her father's death created tensions in the marriage as mentioned above. Tumelo was attending boarding school when his father died. As the only son, he should customarily have taken immediate responsibility for the family and farm; in his absence this fell to his mother and sisters.

Besides the spatial relationship between the young person and dying relative, the spatial organisation of the wider family affects how a death impacts and is responded to. The effect of a non-resident parent's death has been mentioned, but sometimes the surviving parent is absent. Both Janet and Mabatho had a surviving father resident elsewhere when their mother died - though in neither case did they move to live with their father or receive any support. Following a parent's death some young people, whose nearest relative lived away, had to move to be taken care of. Thabo, for instance, moved from lowland Lesotho to the mountains, to herd for his great uncle. Mabatho remained with a sibling but had support from relatives elsewhere. Some young people lived apart from both parents from infancy: Lucy, brought up by her great grandmother, felt her father's death differently from many young people. By contrast, other young people with dispersed kin such as Sharon and Milka experienced multiple moves following their parents' deaths.

The outcomes of AIDS for young people indirectly affected are thus clearly shaped by the temporalities of the disease and of their lives (particularly in relation to age and schooling) and by spatialities such as the location of the individuals concerned and the wider family, and the 
complex ways in which these intersect. While the time-spaces of sickness, death and of young people's own lives are temporally and spatially scaled, this scaling, whether in terms of distance or duration, has impacts that are not directly predictable.

\section{RELATIONAL TIME-SPACE OUTCOMES AND RESPONSES TO AIDS: REX'S STORY}

As the above section hinted, the outcomes for young people of AIDS-related sickness and death in their families are not only affected by the relational time-spaces in/over which the sickness or death occurs but are also (inevitably) expressed in time-space, through actions such as leaving school, marriage or migration that are profoundly temporal and spatial. Again, the timespaces of others (family, friends, acquaintances) intersect with those of the young people, who draw on these relationships in constructing their lifepaths. The diversity and complexity of the strategies adopted by young people affected by AIDS render impractical a broad survey of their temporal and spatial dimensions and the relationalities they encompass. Instead we explore the case of one young man, Rex, aged about 27 when interviewed in August 2008, who had lost both parents in early adulthood and also a young daughter. Use of a single in-depth example illuminates how everyday patterns connect with changes over the lifecourse. Rex's story reveals many ways in which the outcomes for him were structured through relational time-spaces, at various scales, and how he employed particular time-space strategies to construct a life for himself.

We have compiled Rex's story into a broadly linear narrative, based on his responses to interview questions. Constructing the narrative was not straightforward, and involved eliciting years and ages throughout the interview to resolve apparent inconsistencies. We imposed a temporal structure that differs from Rex's own conceptualisation of his experiences (although he undoubtedly retells his experiences in multiple ways). This is problematic (Worth 2009), but allows us more readily to communicate what seem to us the key elements. Since our focus is not on Rex's own conceptions of temporality, but on how he has deployed time-spaces in constructing a dynamic and ongoing life for himself in response to spaced/timed circumstances and relationships, we consider this appropriate. Where timings/spacings remain unclear to us, the inconsistencies are reproduced in the narrative below. Set alongside the narrative is a first 
level analysis that draws out timings and spacings, including their scaling: both time-spaces of parental death and time-spaces of the outcomes and of Rex's responses as he creates an adult life.

\begin{tabular}{|c|c|}
\hline Rex's & $\begin{array}{l}\text { Relational timing and spacing of responses to } \\
\text { AIDS }\end{array}$ \\
\hline $\begin{array}{l}\text { Rex was born in Mozambique to a Malawian } \\
\text { mother and Mozambican father: although } \\
\text { from a matrilocal society, his father had } \\
\text { decided farming was better in Mozambique } \\
\text { and took his wife to live in his village. The } \\
\text { eldest of five sons, Rex went to school and } \\
\text { learned in Portuguese, but visited maternal } \\
\text { relatives in Mulanje, southern Malawi from } \\
\text { time to time. }\end{array}$ & $\begin{array}{l}\text { Cross-national marriages are not unusual in } \\
\text { southern Africa and result in spatially } \\
\text { dispersed families. Customary time-spaces of } \\
\text { marriage are also frequently overridden, } \\
\text { causing children to travel to visit relations they } \\
\text { would otherwise live with, spending time with } \\
\text { them intermittently rather than continuously. } \\
\text { Where the marriage is international, that } \\
\text { travel is international. } \\
\text { Sibling order is a significant temporality. }\end{array}$ \\
\hline $\begin{array}{l}\text { Rex's mother died in } 1999 \text { when he was about } \\
\text { 18. His father wasn't very interested in the } \\
\text { children and wanted to remarry. Rex willingly } \\
\text { 'freed' his father, allowing him to remarry and } \\
\text { move away, leaving Rex and his siblings } \\
\text { behind. Times were hard and they struggled to } \\
\text { eat in } 1999 \text { and 2000, working at times for } \\
\text { nothing but food. The paternal relatives } \\
\text { wanted to divide up the boys, but the village } \\
\text { elders advised them not to take in the children } \\
\text { as they were not their responsibility. Rex was } \\
\text { determined to keep the siblings together-for } \\
\text { their own benefit and to prevent them from }\end{array}$ & $\begin{array}{l}\text { Not only are there customarily-defined time- } \\
\text { spaces of marriage; tradition also specifies } \\
\text { temporal and spatial arrangements for a } \\
\text { family following a death (including in relation } \\
\text { to remarriage). Disruptions to the former } \\
\text { complicate efforts to conform to the latter, } \\
\text { exacerbating the impact of maternal } \\
\text { orphanhood in a matrilocal society. } \\
\text { Sibling order confers responsibilities that } \\
\text { mean that 'orphanhood' can have impacts on } \\
\text { an elder child (particularly a son), even when } \\
\text { that child is legally an adult. } \\
\text { Spatial separation of orphaned siblings is }\end{array}$ \\
\hline
\end{tabular}


destroying other families (presumably through economic costs). He had to provide for his younger brothers including one of 5 months. They sold much of their crop immediately after harvest to buy milk and clothes for the baby, so the food ran out early. He attended school until 1pm then provided casual labour on other people's fields in the afternoon. The original house was falling down, but he built a new one.

In July 2004, when Rex was in Standard $8^{6}$, the last class of primary school, his father died. Immediately, his paternal relatives decided the children were no longer entitled to their father's fields, and seized them, including those on which crops were already planted. Rex remained in school until December to sit his leaving exams. However, because of a severe rainy season, the government could not fly the results to the local centre, and required candidates to travel to another town to collect them. This was too expensive, so Rex never learned whether he passed Standard 8. generally viewed by young people as undesirable.

'Large scale' circumstances and momentous events impinge on 'small scale' time-spaces including young people's daily routines and division of time.
Despite spatial separation between child and parent, the parent's death can have diverse consequences. These consequences relate partly to culturally-specified spatial practices. Being deprived of the time-space of cultivated farmland can deprive a young person of the possibility of a livelihood within a locality. Stage in school can affect whether it is possible (or appropriate) to complete a stage of education and/or progress to the next stage.

Often a coincidence of circumstances (e.g. paternal death followed by adverse wet season) can have profound implications. Technologies of transport and communications over space produce different

\footnotetext{
${ }^{6}$ It is unclear exactly why Rex was so late completing primary education. He told us he missed some years of school because he was an orphan but it is also possible that he is younger than he thinks.
} 


\begin{tabular}{|c|c|}
\hline & frictions of space and of poverty. \\
\hline $\begin{array}{l}\text { With no land to cultivate, and no school } \\
\text { qualification, Rex decided to return to his } \\
\text { mother's home in Mulanje district, Malawi. He } \\
\text { didn't want to leave his brothers as they would } \\
\text { struggle to survive, so they went to Mulanje } \\
\text { too (though one is now back in Mozambique } \\
\text { and others elsewhere). In Mulanje, he found a } \\
\text { friend of his mother's who taught in the town } \\
\text { of Luchenza. They got on well and he moved to } \\
\text { Luchenza where she became like a second } \\
\text { mother. She also gave him private tuition for } \\
\text { Malawian Standard } 4 \text { and } 5 . \text { He found it } \\
\text { difficult to learn in English, although his grasp } \\
\text { of the subject matter was good. After some } \\
\text { to Nihelo to care for her. Rex is now building a } \\
\text { months, she got married and moved away. He } \\
\text { decided it wasn't worth continuing with } \\
\text { education but was time to get married instead. } \\
\text { fot being familiar with women in Malawi, he } \\
\text { asked a friend to find him a wife who would be } \\
\text { fomeone who had already experienced }\end{array}$ & $\begin{array}{l}\text { Spatio-temporal circumstances, including both } \\
\text { sudden events (a father's death and } \\
\text { associated loss of land) and long established } \\
\text { connections (relationships built over time) } \\
\text { shape the decision to migrate and choice of } \\
\text { destination, whether international or local. } \\
\text { International migration requires not only the } \\
\text { means to span space but also a commitment } \\
\text { of time - to learn a new language - that feels } \\
\text { scarcer as a young person grows older. } \\
\text { Arrangements are unstable and subject to } \\
\text { time-space shifts such as the marriage (and } \\
\text { associated spatial relocation) of a teacher. } \\
\text { Poverty, lack of relevant or certified education } \\
\text { and lack of cultural knowledge, associated } \\
\text { with parental death and consequent } \\
\text { international migration, all restrict a young } \\
\text { person's choice of marriage partner, and may } \\
\text { increase their likelihood of marrying someone } \\
\text { suspected of being HIV-positive. } \\
\text { Marriage is spatially and temporally } \\
\text { structured, with expectations as to where } \\
\text { either party will live and how soon a house } \\
\text { should be built. }\end{array}$ \\
\hline
\end{tabular}




\begin{tabular}{|c|c|}
\hline $\begin{array}{l}\text { house in Nihelo, as is customary among } \\
\text { southern Malawians. }\end{array}$ & \\
\hline $\begin{array}{l}\text { While in Luchenza, in February/March 2005, } \\
\text { Rex spent two months doing domestic work for } \\
\text { an NGO worker who was subsequently } \\
\text { transferred to the distant capital of Lilongwe. } \\
\text { He did not move with his boss, but the boss } \\
\text { invited Rex to his home village in Nsanje, in the } \\
\text { far south of Malawi, to clear trees from some } \\
\text { land to prepare it for sale. Rex was allowed to } \\
\text { sell the wood for firewood and keep the } \\
\text { MK5,000' it fetched. This, along with a } \\
\text { MK10,000 loan from a friend, enabled him to } \\
\text { start a business buying and selling fish in } \\
\text { Nsanje. He learned about fish trading when } \\
\text { doing casual work for people engaged in the } \\
\text { trade. He chose this business 'because it is not } \\
\text { difficult, it is profitable within a short time and } \\
\text { it is not seasonal'. After three months, having } \\
\text { accumulated MK30,000, he began to transport } \\
\text { fish to sell in Luchenza. While he was in } \\
\text { Nsanje, his wife returned to Nihelo, as he } \\
\text { couldn't afford her fare to Nsanje. }\end{array}$ & $\begin{array}{l}\text { Long distance and relatively sudden work } \\
\text { transfers are common in southern Africa and, } \\
\text { like marriage, their temporal and spatial } \\
\text { dimensions have implications not only for } \\
\text { those directly involved. } \\
\text { Freedom and ability to travel when a chance } \\
\text { arises (even despite marriage) can provide } \\
\text { valuable livelihood opportunities. } \\
\text { Proximity in time and space provides scope to } \\
\text { learn of livelihood opportunities. } \\
\text { Young people's decision-making in relation to } \\
\text { livelihoods may take into account both } \\
\text { temporal and spatial aspects. Trading can be } \\
\text { more profitable when it spans a larger space, } \\
\text { although it requires greater investment. }\end{array}$ \\
\hline $\begin{array}{l}\text { In December } 2007 \text { the fish business collapsed, } \\
\text { largely because he used up the capital he } \\
\text { needed to buy further fish for resale. Rex gave }\end{array}$ & $\begin{array}{l}\text { Even longer distance ventures, involving } \\
\text { international migration, while requiring higher } \\
\text { investment, may be yet more beneficial. }\end{array}$ \\
\hline
\end{tabular}

\footnotetext{
${ }^{7}$ Approximately $£ 20$.
} 


\begin{tabular}{|c|c|}
\hline $\begin{array}{l}\text { MK15,000 of his capital to his younger brother } \\
\text { to get a passport to go to South Africa, in the } \\
\text { hope that this would benefit the whole family. } \\
\text { He has heard very little from his brother since, } \\
\text { other than a rumour that he is now in } \\
\text { Namibia. (Another brother went to South } \\
\text { Africa earlier, and Rex kept in touch with him } \\
\text { using the teacher's phone when he was in } \\
\text { Luchenza, but this is no longer possible). A } \\
\text { further MK10,000 was given to a friend for } \\
\text { safekeeping. The friend had a car accident and } \\
\text { used the money to pay for hospital fees. The } \\
\text { remainder of his capital was spent on a funeral } \\
\text { for his only child - a baby daughter - who died } \\
\text { in early January. }\end{array}$ & $\begin{array}{l}\text { However, this is riskier, and is very hard to } \\
\text { control when it involves sending another } \\
\text { family member rather than travelling oneself. } \\
\text { Control over space, using communications } \\
\text { technologies, is easier when located in some } \\
\text { places than others. } \\
\text { The death of a child, as much as another } \\
\text { relative, can be a significant event for a young } \\
\text { person, both emotionally and economically. }\end{array}$ \\
\hline $\begin{array}{l}\text { Since December Rex has been surviving in } \\
\text { Nihelo on casual work as he has no money to } \\
\text { invest in business. He would like to use his } \\
\text { skills as a builder. He has built three houses: } \\
\text { one in Mozambique, one in Nihelo, and one in } \\
\text { Luchenza for which he was paid MK600. } \\
\text { However, in Nihelo people tend to favour their } \\
\text { relatives when employing builders. He aspires } \\
\text { to open a grocery business, or to go and buy } \\
\text { things in South Africa to sell in Malawi. }\end{array}$ & $\begin{array}{l}\text { Being a migrant restricts social networks and } \\
\text { potentially therefore opportunities in the } \\
\text { place of destination. This applies to most } \\
\text { married men in a matrilocal society, not only } \\
\text { international migrants. }\end{array}$ \\
\hline
\end{tabular}

Rex's story reveals not only the events that befell him and how the spatial and temporal circumstances surrounding those events shaped their impacts on his life. It also outlines a 
sequence of actions that he undertook and the attendant circumstances and consequences that have constituted his lifecourse experiences and brought him to his current situation. Rex did not accomplish a straightforward linear transition, although he left school, left home, found work, married and had a child, all in the culturally prescribed sequence. The timing and circumstances of these events was dictated in part by customary propriety, but significantly by the impacts of AIDS and the relational time-space context. Where his father was when he died is not of apparent relevance. Where Rex was at this moment (in relation to others and at that point in his life) was profoundly significant - to where he went subsequently, how he made a living and whom he chose to marry. Rex's story is one of individual agency: he is in some respects an unusual individual, perhaps more willing than most to relocate to improve his own lifechances (although levels of economic migrancy among youth in Nihelo are high). He made decisions, employing time-space in selected ways, some of which 'worked out', while others were thwarted. Yet focusing on Rex as an individual reveals little. All his decisions were taken in relation to broader circumstances and, in particular, the actions and needs of other people: his parents, extended family, community members, friends, siblings, employer and wife. Once married, for instance, Rex's own mobility was intimately connected to that of his wife, although not isomorphically. This reinforces the arguments of Massey (2005) and others that time-space is fundamentally relational, structured by social relationships as well as cultural practices and economic activities.

Moreover, although structural circumstances do not emerge prominently in his narrative, Rex was also constructing his life in relation to wider political contexts - national boundaries and their implications, economic unevenness (between towns and between countries). This echoes Langevang's (2008) observations concerning youth in Ghana. Rex's story also demonstrates how customary spatio-temporal arrangements that govern the political-economies of marriage and childrearing both constrain and are being defied or adapted.

Rex's narrative is one of momentous events more than everyday patterns, partly because of the way it was elicited. But the everyday contributes to momentous events (see Worth 2009): the daily hunger that persuaded Rex to leave Mozambique; his routine observation of how others 
were making money; growing frustration with his failure to make headway in learning English. His life weaves together differently scaled time-spaces to produce a livelihood: the division of the day between school and work; of life between education and work; engaging in different businesses over different times and spaces, depending on availability of capital and social relationships.

Rex's fate reflects to some degree his command over space at different points in his life. His mobility at times advantaged him: moving to Malawi from Mozambique, or trading fish from Nsanje to Luchenza offered meaningful opportunities. But space is not only distance travelled: it is fundamentally social and multidimensional. Rex ordered his life in relation to places near and far (see Latham 2002), as well as moving between them. His command over physical area, and virtual and indirect mobilities, networks and flows, mattered: loss of access to agricultural land; inability to access exam results by mail or telephone; capacity to buy a passport for a brother; and mobile phone communications with brothers in South Africa possible from Luchenza but not from Nihelo. Command over all these forms of space requires resources. Valuable time-spaces also included a time-displaced relationship with his mother's friend in Luchenza, indicating how personal relationships endure over time, space and organisational boundaries after individuals move (Agrawal et al 2006), and even between generations.

\section{CONCLUSIONS}

In summary, relational time-spaces shape young people's experiences of familial sickness and death from AIDS, the outcomes for them and their active responses. These include the timespaces of sickness and death (when, where etc); the time-spaces of young people's everyday lives and of their lifecourse trajectories; and the time-spaces of their families and wider circumstances, that are embedded in the time-space structuring of southern African societies. All of these are dynamic and intersect in complex ways. They are partly scalar (ranging from everyday to once-in-a-lifetime; from local to global), but invariably the scales are co-implicated (see Massey 2005). They also incorporate other dimensions of spatiality and temporality: access to land; embodied or virtual/indirect command over distance; regularity of repetition; reference to memory. Some serve as barriers in time and space across which existing everyday 
lives cannot be transferred (national borders; changes in status when a parent dies, on marriage or leaving school); others involve more reversible or repetitious happenings. The space-times of AIDS-related events, and of the young lives they impact, shape life chances in many ways, presenting both constraints and opportunities. However, time-spaces do not simply shape lifecourses; as Massey (2005) suggests, they are open, always being made, and are produced and deployed as much as demarcating and restricting.

A relational time-space perspective helpfully illuminates AIDS' varied impacts on young people, highlighting that because of the diversity of timings and spacings of young people's lives and of sickness and death, young people experience the sickness and death of parents and others in very different ways; AIDS-affected young people are far from homogeneous. Stewart (2005) has argued for attention to the importance of time-space relative to vulnerable populations; the significance of time-spaces of AIDS-related sickness and death to the young people affected remains largely unrecognised. So are the contexts in which they occur: a time-space perspective allows AIDS to be contextualised more fully in relation to both everyday life and young people's wider lifecourse trajectories. Young people's lives can differ radically from one year to the next, and consequently AIDS affects them differently. Due to fast paced change and once-in-alifetime decisions (dropping out of school, getting married, deciding on livelihood focus), AIDSrelated emotional and financial problems hitting at the wrong time can have far-reaching effects: timings matter more than they generally do for mature adults. Both everyday lives and broader lifecourses are lived profoundly in relation to others - to families, friends, institutions (Hopkins and Pain 2007). These three interrelated aspects of the contexts in which young people experience familial sickness and death both affect, and are in turn transformed through, that experience and through young people's responses to it.

Recognition of the time-spaces of AIDS' impacts on young people thus draws attention to contexts, and does so in a much broader way than has been common hitherto. Importantly, this highlights the reality that AIDS is but one of the situations faced by young people that shape their lives. AIDS may transform lifecourses, but so do other events, and for those affected, the outcomes interweave. Equally significantly, the relational time-space contexts that shape the 
outcomes of AIDS for young people, while diverse, are not purely random. They are underlain by assorted time-space rules that pose constraints on young people's experiences and responses. 'Time-space geometries' (Panelli 2007) express power relations that do not always operate to the benefit of all. Time-spaces of sickness, death and dealing with the consequences of death are socially/culturally prescribed, albeit not unchanging. These can facilitate positive outcomes, but they inevitably impose some costs on some individuals. Moreover, the ways in which a spatio-temporally ordered society deals with ruptures - such as a family like Rex's that locates in the customarily 'wrong' village - can have adverse consequences for some. Adopting a time-space lens reveals how current social mechanisms, including those for addressing sickness and death, intersect with the time-spaces of youth to shape young people's timespaced responses.

A relational time-space approach to understanding the lives of AIDS-affected young people is thus valuable in explaining some of the diversity in experiences and outcomes, and in reminding us not to assume that young people are likely to be affected by even common experiences in similar or predictable ways. It might allow for an identification of critical time-spaces - such as parental deaths that affect children in the final year of primary school or in secondary school, or in the period between leaving school and marrying, or the death of a non-resident provider for more accurate targeting of appropriate forms of support. It is, however, important to recognise that any categorisation of this form leads to a loss of complexity, and the stories of Rex and other young people reveal the highly contingent nature of their experiences.

More importantly, a focus on relational time-spaces encourages us to move beyond the individual, to see young people in relation to their wider contexts and in particular their relationships with others, as these are so significant in shaping outcomes. There are aspects of these contexts that limit young people's options, and sometimes force them into disadvantageous lifecourse decisions (Langevang 2008), that might usefully be addressed through policy or other interventions. These include, for instance, expectations concerning responsibility for orphans living in the 'wrong' community, young people being able to start or 
return to school when 'over-age' and to access exam results they have worked for, or enabling young people to access property they should inherit from non-resident parents.

Finally, an application of time-space thinking to AIDS-affected young people can contribute to the theorisation of time-space in relation both to everyday lives and to lifecourses and their interrelationships. Lifecourses connect to everyday lives with outcomes that are produced in ways that are profoundly relational, particularly as AIDS can remove key relationships (through death) or change the nature of those relations (through sickness). Moreover, much research has examined either the mobilities associated with lifecourse stages (Clark and Huang 2003; McHugh et al 1995; Ní Laoire 2008), or migrations due to particular events (including AIDSrelated deaths (Ansell and van Blerk 2004)); this paper elaborates how events happen in relation to the lifecourse, and shape young people's lifecourse trajectories (see also Worth 2009). The loss of parents can, for instance, lead young people to more rapid transitions to adulthood (leaving school earlier, marrying earlier) and to forge paths to independence (in contrast to the 'negotiated interdependence' Punch (2002) describes in Bolivia). Equally, the paper makes clear the limitations of studying either lifecourses or everyday lives in isolation: AIDS-related sickness and death intervene, spatially and temporally, in the time-spaces of both young people's lifecourse trajectories and their everyday lives, and it is the conjunction of these temporalities that constitute outcomes.

\section{REFERENCES}

Adam B, 2004, Time Polity Press, Cambridge

Agrawal A, Cockburn I and McHale J, 2006, "Gone but not forgotten: Knowledge flows, labor mobility, and enduring social relationships" Journal of Economic Geography 6 571-591

Ali S, 1998, "Community perceptions of orphan care in Malawi" Raising the orphan generation, Pietermaritzburg, 9-12 June 1998

Ansell N and van Blerk L, 2004, "Children's migration as a household/family strategy: coping with AIDS in Malawi and Lesotho" Journal of Southern African Studies 30 673-690 
Ansell N, 1999, "Southern African secondary schools: places of empowerment for rural girls? Cases from Lesotho and Zimbabwe" Unpublished PhD thesis, Keele University

Ansell N, 2004, "Secondary schooling and rural youth transitions in Lesotho and Zimbabwe" Youth and Society 36 183-202

Ansell N, 2009, "Childhood and the politics of scale: Descaling children's geographies?" Progress in Human Geography 33 190-209

Bailey AJ, 2009, "Population geography: Lifecourse matters" Progress in Human Geography 33 407-418

Beck U, 1994, "The reinvention of politics: towards a theory of reflexive modernization" in Beck $\mathrm{U}$, Giddens A and Lash S (eds) Reflexive modernization Polity Press, Cambridge

Benwell MC, 2009, "Challenging minority world privilege: Children's outdoor mobilities in postapartheid South Africa" Mobilities 4 77-101

Billari FC, Philipov D and Baizal̀n, P, 2001, "Leaving home in Europe: The experience of cohorts born around 1960" International Journal of Population Geography 7 339-356

Booysen F, 2006, "Out-migration in the context of the HIV/AIDS epidemic: Evidence from the Free State Province" Journal of Ethnic and Migration Studies 32 603-631

Chanock M, 1985, Law, custom and social order: the colonial experience in Malawi and Zambia Cambridge University Press, Cambridge

Clark WAV and Huang Y, 2003, "The life course and residential mobility in British housing markets" Environment and Planning A 35 323-339

Cooke TJ, 2008, "Migration in a family way" Population, Space and Place 14 255-265

Cope M, 2007, “Children's urban geographies” The challenges of time and space, ESRC Seminar, Newcastle, 6-7 December 
Crang M, 2005, "Time space" In Spaces of geographical thought: deconstructing human geography's binaries Cloke P and Johnston R Sage, London pp 199-217

De Jong GF and Roempke Graefe D, 2008, "Family life course transitions and the economic consequences of internal migration" Population, Space and Place 14 267-282

Dobson J and Stillwell J, 2000, "Changing home, changing school: towards a research agenda on child migration" Area 32 395-401

Dodgshon RA, 2008, "Geography's place in time" Geografiska Annaler, Series B: Human Geography 90 1-15

Elder GH, 1998, "The life course and human development" in The handbook of child psychology, Ed W Damon (Wiley, New York) pp 939-991

Ellegård K and Vilhelmson B, 2004, "Home as a pocket of local order: Everyday activities and the friction of distance" Geografiska Annaler, Series B: Human Geography 86 281-296

Ennew J and Swart-KrugerJ, 2003, "Introduction: Homes, Places and Spaces in the Construction of Street Children and Street Youth" Children, Youth and Environments 13

Ferguson J, 1990, The anti-politics machine: "development", depoliticization and bureaucratic power in Lesotho (CUP, Cambridge)

Ford K and Hosegood V, 2005, "AIDS mortality and the mobility of children in Kwazulu Natal, South Africa" Demography 42 757-768

Giddens A, 1991, Modernity and self-identity: self and society in the late modern age (Stanford University Press, Stanford)

Ginsburg C, Norris S A, Richter LM and Coplan DB, 2009, "Patterns of residential mobility amongst children in Greater Johannesburg-Soweto, South Africa: Observations from the birth to twenty cohort" Urban Forum 20 397-413 
Gough KV, 2008, "'Moving around: The social and spatial mobility of youth in Lusaka" Geografiska Annaler, Series B: Human Geography 90 243-255

Gregory D, 2009, "Space" in Gregory D, Johnston R, Pratt G, Watts MJ and Whatmore S, 2009, The dictionary of human geography Wiley-Blackwell, Chichester

Harker C, 2005, "Playing and affective time-spaces" Children's Geographies 347 - 62

Heaton TB, Forste R and Otterstrom SM, 2002, "Family transitions in Latin America: First intercourse, first union and first birth" International Journal of Population Geography 8 1-15

Holloway SL and Valentine G, 2000, "Spatiality and the new social studies of childhood" Sociology $34763-783$

Hopkins P and Pain R, 2007, "Geographies of age: Thinking relationally" Area 39 287-294

Hörschelmann K and Schafer N, 2005, "Performing the global through the local: globalisation and individualisation in the spatial practices of young East Germans" Children's Geographies 3 219-242

Horton J and Kraftl P, 2006, “Not just growing up, but going on: materials, spacings, bodies, situations" Children's Geographies 4259 - 276

Horton J, 2008, "A 'sense of failure'? Everydayness and research ethics" Children's Geographies 6(4) 363-383

James A, Jenks C and Prout A, 1998, Theorising childhood. (Teachers College Press, New York) Jones G and Wallace C, 1992, Youth, family and citizenship (Open University Press, Buckingham) Kachika T, c2000, Thoughts on the applicability of local inheritance laws on intestacy to women: is there hope for the woman? mimeo

Katz C, 2004, Growing up global: economic restructuring and children's everyday lives (University of Minnesota Press, Minneapolis) 
Kraftl P, Barker J, Horton J, Tucker F, 2009, “The Road Less Travelled: Children and Young People's Mobility" Mobilities 4 1-10

Langevang T and Gough K, 2009, "Surviving through movement: the mobility of urban youth in Ghana" Social and Cultural Geography $10741-756$

Langevang T, 2007, "Movements in time and space: using multiple methods in research with young people in Accra, Ghana" Children's Geographies 5 267-282

Langevang T, 2008, “'We are managing!' Uncertain paths to respectable adulthoods in Accra, Ghana" Geoforum 39 2039-2047

Latham A, 2002, "Retheorizing the scale of globalization: topologies, actor-networks, and cosmopolitanism" in Herod A and Wright M W (eds) Geographies of power: placing scale Blackwell, Oxford, pp. 115-144

Letuka P, Mamashela MP, Matashane K, Mbatha L and Mohale M, 1994, Inheritance in Lesotho. Women and Law in Southern Africa Research Project

Massey D, 1998, "The spatial construction of youth cultures" in Skelton T and Valentine G (eds) Cool places: geographies of youth cultures Routledge, London

Massey D, 2005, For space (Sage, London)

McDowell L, 2002, "Transitions to work: Masculine identities, youth inequality and labour market change" Gender, Place and Culture 9 39-59

McHugh KE, Hogan TD and Happel SK, 1995, "Multiple residence and cyclical migration: a life course perspective" Professional Geographer 47 251-267

Murray C, 1981, Families divided: the impact of migrant labour in Lesotho Cambridge University Press, Cambridge

Ní Laoire C, 2008, "'Settling back'? A biographical and life-course perspective on Ireland's recent return migration" Irish Geography 41 195-210 
Panelli R, 2007, "Time-space geometries of activism and the case of mis/placing gender in Australian agriculture" Transactions of the Institute of British Geographers 32 46-65

Punch S, 2002, "Youth transitions and interdependent adult-child relations in rural Bolivia" Journal of Rural Studies 18 123-133

Punch S, 2007, "Negotiating migrant identities: young people in Bolivia and Argentina" Children's Geographies 5 95-112

Richter LM, Norris SA, Swart TM and Ginsburg C, 2006, "In-migration and living conditions of young adolescents in Greater Johannesburg, South Africa" Social Dynamics 32 195-216

Robson E, Ansell N, Huber U, Gould W and van Blerk L, 2006, "Young caregivers in the context of the HIV/AIDS pandemic in sub-Saharan Africa" Population, Space and Place 12 93-111

Ruddick S, 2003, "The politics of aging: globalization and the restructuring of youth and childhood" Antipode 35 334-362

Schatzki TR, 2006, "The time of activity" Continental Philosophy Review 39 155-182

Shove E, 2007, "Routines and rhythms of everyday practice" Time-Space and Life-Course seminar, Lancaster University, $1^{\text {st }}$ May

Skelton T, 2009, "Children's geographies/geographies of children: Play, work, mobilities and migration" Geography Compass 3 1430-1448

Stewart E, 2005, "Exploring the vulnerability of asylum seekers in the UK" Population, Space and Place 11 499-512

Teather E, Ed, 1999 Embodied geographies: spaces, bodies and rites of passage (Routledge, London)

Tucker F, 2003, “Sameness or Difference? Exploring Girls' Use of Recreational Spaces” Children's Geographies 1 111-124 
Uprichard E, 2008, "Children as 'being and becomings': children, childhood and temporality" Children and Society 22 303-313

US Census Bureau, 2009, International Data Base (IDB)

http://www.census.gov/ipc/www/idb/informationGateway.php accessed 10/01/2010

van Blerk L and Ansell N, 2006, "Children's experiences of migration: Moving in the wake of AIDS in southern Africa" Environment and Planning D: Society and Space 24 449-471

van Blerk L, 2008, "Poverty, migration and sex work: Youth transitions in Ethiopia" Area 40 245253

White L, 1987, Magomero: portrait of an African village (Cambridge University Press, Cambridge)

Worth N, 2009, "Understanding youth transition as 'Becoming': Identity, time and futurity" Geoforum 40 1050-1060 